\author{
SYMPOSIUM: \\ RISK MANAGEMENT ISSUES IN SPORTS
}

\title{
Equality of Access to Emergency Services for People with Disabilities Under the Americans with Disabilities Act
}

\author{
JOHN GRADY \\ University of South Carolina \\ $\&$ \\ DAMON P. S. ANDREW \\ The University of Tennessee
}

\section{INTRODUCTION}

Ed Beyea, a quadriplegic wheelchair user, had come a long way since he became disabled after a diving accident at age 22. Now 42 years of age, he had managed to work 14 years as a program analyst at Blue Cross/Blue Shield in his office on the $27^{\text {th }}$ floor of One World Trade Center. Ed needed 24-hour nursing assistance, but otherwise led as normal a life as possible. He took the subway to work, used a mouthpiece to tap the keys on his computer, and kept himself busy with books, movies, television, and dinners with friends.

On the morning of September 11th, 2001, Ed's health aide, Irma, had gone to pick up breakfast on the $43^{\text {rd }}$ floor when the plane struck the tower. She hurried back to the $27^{\text {th }}$ floor and found Ed and his best friend Abe Zelmanowitz waiting for help in the stairwell. Weighing approximately 300 pounds, Ed needed special assistance in order to evacuate the building. $\mathrm{He}$ wanted to wait until he could be securely carried down by several rescue workers, as it was dangerous for someone with his disability to be moved. Abe volunteered to stay with Ed, suggesting Irma leave because she was coughing. When she reached the lobby, she found a fireman and told him where Ed was. Both Ed and Abe called their families to let them know that they were okay, and it seems that with the help of some people, they were able 
to make it down to the $21^{\text {st }}$ floor before the building collapsed (Byzek \& Gilmer, 2001).

While Ed and his faithful companion Abe did not survive the collapse of the World Trade Center building, John Abruzzo, a quadriplegic power wheelchair user, successfully evacuated the building from the $69^{\text {th }}$ floor with the help of his courageous coworkers and an EVAC + CHAIR, a rescue device that resembles a large, folding baby stroller with rear wheels that pop up and a sled-like component that takes their place when going down stairs. John and his coworkers exited the tower and were out of harm's way ten minutes before the building's collapse.

The tragedy of September 11th, 2001, highlighted the importance of emergency planning, particularly for individuals with disabilities. While one can hope that such acts of terrorism are rare, other catastrophic events such as floods, tornadoes, hurricanes, and fires are frequent occurrences across this nation and can lead to tragic results (White, Fox, Rowland, \& Rooney, 2004). The stories of Abe and John, recounted above, demonstrate how proper emergency planning can produce vastly different outcomes. These stories are also analogous to the routine fears faced by individuals with disabilities who patronize sports facilities. Given the challenges presented by having patrons seated at multiple levels of an arena, the patrons' reliance on elevators as the primary means of evacuation, and the necessity of a staff member or companion assisting them, the concerns of these patrons in being able to effectively evacuate during an emergency are realized. This realization, in turn, also highlights the obligation of facility managers to ensure the patrons' safety during emergency situations.

\section{BACKGROUND}

Individuals with disabilities comprise a sizable portion of the general population of the United States. According to the U.S. Census of 2000, they represent 19.3 percent of the 257.2 million people ages 5 and older in the civilian noninstitutionalized population. The National Council on Disability (2005) defines individuals with disabilities as those who are "vulnerable" or "at risk" and cannot always comfortably or safely use some of the standard resources offered in disaster preparedness, relief, recovery, and mitigation. This definition of "disability" used by disability advocates differs from the definition provided in the Americans with Disabilities Act ("ADA") itself. The ADA defines a person with a disability as a person with a physical or mental impairment that substantially limits one or more major life activities, or has a record of such a physical or mental impairment, or is regarded as having 
such a physical or mental impairment (42 U.S.C. § 12102(2), 2006). As such, this group may include people who have a variety of visual, hearing, mobility, cognitive, emotional, and mental limitations, as well as older people, people who use life-support systems, people who use service animals, and people who are medically or chemically dependent. Adopting such a broad definition helps to ensure that no one is left behind in an emergency, and the imperative is clear that everyone address the broad spectrum of disability and activity limitation issues (Reis, Breslin, Iezzoni, \& Kirschner, 2004). If emergency planning does not embrace the value that everyone should survive, the process will ultimately be unsuccessful.

Although it would seem that the events of September 11th, 2001, would have created widespread change and innovation related to disaster preparedness for all individuals, including people with disabilities, this has not been the case. A December 2003 Harris poll found only 44 percent of people with disabilities knew whom to contact to get information in times of disaster or emergency, compared with 40 percent in a 2001 poll conducted soon after the events of September 11th (National Organization on Disability, 2001; 2004). The National Organization on Disability (N.O.D.) was disappointed to learn that in 2002, only 39 percent of people surveyed had a plan for evacuating their home in the event of an emergency, compared with the 38 percent who had a plan in the 2001 survey. People with disabilities also noted higher rates of anxiety than were found in the general population about future disasters and emergencies (N.O.D., 2004). Since disaster preparedness and emergency response systems are typically designed for people without disabilities, for whom escape or rescue involves walking, running, driving, seeing, hearing, and quickly responding to directions (White et al., 2004), perhaps a higher rate of anxiety is justified.

While there is a wealth of disaster related anecdotal accounts from the disability community in the popular press, the disability press, and in meeting minutes, unpublished reports, and correspondence, few studies have explored the experiences of people with disabilities and activity limitations in disaster activities that include planning, mitigation, preparedness, response, and recovery (Pollander \& Rund, 1989; White et al., 2004). Unfortunately, the majority of these studies indicate the same access mistakes appear to be made repeatedly in disaster management activities. In addition, these studies found that lessons learned after a disaster about reducing access barriers are not subsequently integrated into common practice. Such barriers include access to physical plants, communications, and programs in recovery centers as well as other structures and buildings used in connection with disaster operations, which may present barriers to identification, access, management, training, 
and services (California Department of Rehabilitation, 1997; California State Independent Living Council, 2004; Center for Independence of the Disabled, 2004; Kailes, 2000; U.S. Department of Justice 2004, White et al., 2004). While the occurrence of disasters as impactful as the September 11th tragedy are admittedly quite rare, risk managers need to be prepared for such disasters as well as more common emergencies, such as evacuating a building during a fire drill. Moreover, many of the same strategies that have evolved as a result of large-scale disasters can be successfully implemented into the operations at places of public accommodation, including sport and entertainment venues, albeit on a much smaller scale. Title III of the ADA defines "public accommodations" in terms of twelve categories of private entities, if their operations affect commerce (42 U.S.C. \$12181(7), 2006). The twelve categories include such places as hotels, restaurants, stadia, and shopping centers (42 U.S.C. $\$ 12181(7), 2006)$.

While acknowledging the significant progress that has been made in improving facility accessibility for patrons with disabilities in sport and entertainment venues since enactment of the Americans with Disabilities Act (42 U.S.C. \$12101, et. seq., 2006), an especially challenging issue in accommodating patrons with disabilities in sport and entertainment venues is the development of emergency procedures. The challenge exists not only because emergency plans are typically designed with able-bodied guests in mind (White et al., 2004), but also because such plans are often designed by able-bodied facility managers without any substantial input from people with disabilities. Facility managers have begun to recognize that the challenges in developing effective emergency procedures for people with disabilities, particularly with regard to safe evacuation, are not only practically significant, but also present an emerging area of legal liability for the sport and entertainment venue industries (McGuire, 2005). Thus, the need to ensure proper emergency planning for all patrons, including patrons with disabilities, remains a priority not only because of the critical need to save lives during an emergency, but also because the role of proper planning as part of an overall ADA compliance strategy serves to avoid litigation and the resulting negative publicity arising from allegations of violation of anti-discrimination laws such as the ADA. Through the cases analyzed below, the legal issues relevant to emergency planning and evacuation will be explored and recommendations to improve the effectiveness of emergency planning efforts will be forwarded.

Section One of this paper presents the legal obligation imposed on sport and entertainment venues to safely evacuate patrons with disabilities under the ADA and its interpretive guidelines (U.S. Architectural and Transportation Access Board, n.d., hereinafter "ADAAG"). Section Two analyzes the ruling 
in Savage v. City Place Limited (2004) and examines the impact of the Savage case on disability law and policy. Section Three presents risk management strategies focused on including the needs of people with disabilities in emergency plans and the integration of such a plan into the venue's comprehensive risk management strategy.

\section{SECTION ONE: LEGAL OBLIGATIONS IN EVACUATING PATRONS WITH DISABILITIES}

Several laws and interpretive guidelines, including the ADA and ADA Accessibility Guidelines (ADAAG), are relevant to the evacuation of people with disabilities from places of public accommodation. The patchwork of laws and guidelines effectively overlap to create a legal landscape which, in theory, should ensure safe evacuation in case of emergency. However, given the inconsistency in how these laws and guidelines have been interpreted by the courts and service providers, the legal obligation to safely evacuate patrons with disabilities was, until recently, murky at best because there was not a clear answer to the question of whether Title III of the ADA applied to emergency plans. It was only recently that a court expressly held that the ADA applied to the evacuation procedures of a place of public accommodation under Title III (Savage v. City Place Limited, 2004)). Until the Savage (2004) decision, "there had been no court rulings specifying that companies are required to draw up [evacuation] plans with disabled people in mind" (NOD, 2005a, p. 1).

Section 12182 of the ADA outlines the legal obligation to safely evacuate people with disabilities (42 U.S.C. $\S 12182,2006$ ). Title III of the ADA applies to places of public accommodation operated by private entities. This would include a wide range of sport and entertainment venues, such as stadia, arenas, convention centers, and performing arts centers. Title III of the ADA mandates that

No individual shall be discriminated against on the basis of disability in the full and equal enjoyment of the goods, services, facilities, privileges advantages, or accommodations of any place of public accommodation by any person who owns, leases (or leases to), or operates a place of public accommodation (42 U.S.C. § 12182(a)).

A Title III violation occurs where the place of public accommodation "fail[s] to make reasonable modification in policies, practices, or procedures, when such modifications are necessary to afford such [goods and services] . . to individuals with disabilities, unless the entity can demonstrate 
that making such modifications would fundamentally alter the nature of such goods, services, . . or accommodations" (42 U.S.C. $§ 12182(b)(2)(A)(i i)$ ).

In addition to the ADA, the ADA's accessibility guidelines (ADAAG) as well as the ADA Title III Technical Assistance Manual both cite the need to include specific provisions in their emergency plans to ensure the safe evacuation of people with disabilities in places of public accommodation and other entities subject to the ADA (McGuire, 2005). "The ADAAG, which primarily cover new construction and alterations, include specifications for accessible means of egress, emergency alarms, and signage" (U.S. Architectural and Transportation Access Board, n.d.). For example, "[m]ost of the criteria for accessible routes ... are applied to accessible means of egress to ensure access for persons with disabilities, including those with mobility impairments" (U.S. Architectural and Transportation Access Board). Additionally, the Appendix to ADAAG states: "Because people with disabilities may visit, be employed, or be a resident in any building, emergency management plans with specific provisions to ensure the safe evacuation also play an essential role in fire safety and life safety" (U.S. Architectural and Transportation Access Board, n.d., A4.3.10). While the ADAAG provisions are intended to provide facility managers with more specific guidance as to how the ADA should be applied in facilities subject to its compliance, it is unclear why sport facility managers continue to experience barriers in implementing such provisions into their venue operations.

The ADA Title III Technical Assistance Manual, which is designed "to assist individuals and entities in understanding their rights and duties under the [ADA]" (ADA Title III Technical Assistance Manual, 1993), also provides guidance to facility managers with regard to emergency evacuation. The ADA Title III Technical Assistance Manual states that a facility

is obligated to modify its evacuation procedures, if necessary, to provide alternative means for clients with mobility impairments to be safely evacuated ... without using the elevator. The [facility] should also modify its plan to take into account the needs of its clients with visual, hearing, and other disabilities (ADA Title III Technical Assistance Manual, III-4.2100 General, Illustration 1).

In addition to the "focused, systematic description of the ADA's requirements" (ADA Title III Technical Assistance Manual, Introduction) provided in the Technical Assistance Manual as well as the guidance found in the ADAAG, the judiciary has also provided their interpretation of the provisions of the ADA and the obligations imposed on places of public accommodations to 
reasonably accommodate patrons with disabilities. These judicial interpretations are analyzed below.

\section{Significant Disability Cases in Sport}

Anderson v. Little League Baseball (1992) and PGA Tour v. Martin (2001) are two significant cases in sport that have interpreted Title III's nondiscrimination provisions as well as the defenses available to places of public accommodation. These cases illustrate the legal framework by which a person with a disability has the right to challenge a denial of their equal right to participate in sport both as a participant or spectator. Analysis of these cases highlights how courts have interpreted and applied the ADA in those cases specifically challenging discriminatory policies or practices for people with disabilities rather than the bulk of ADA cases that challenge the lack of accessibility of the physical facilities under Title III. Discussion of the Anderson (1992) and Martin (2001) cases is followed by an analysis of evacuation cases involving people with disabilities to show how the courts interpretation of Title III of the ADA has, over time, evolved to require equitable evacuation procedures for people with disabilities in places of public accommodation.

Anderson v. Little League Baseball (1992) involved a challenge by a Little League Baseball coach in a wheelchair. Little League Baseball had adopted a policy regarding base coaching whereby a "... (coach in [a] wheel chair) may coach from the dugout, but cannot be in the coaches box" (Anderson, p. 343). The stated rationale behind the rule was the safety considerations of the youth baseball players in not having "the added concern of avoiding a collision with a wheel chair during their participation in the game" (p. 343). Despite several attempts to get the association to reconsider the policy, Little League Baseball reaffirmed the policy (p. 343). Prior to the 1992 season-ending tournament, Anderson believed that, because of the policy, he would not be allowed to coach on the field despite having been selected as a coach in the tournament, and would also not be allowed to coach on the field during the following season (Anderson, 1992). Given these concerns, Anderson filed an action for declaratory and injunctive relief seeking to restrict Little League Baseball from "preventing [him] from participating fully, coaching on the field, or otherwise being involved to the full extent of his responsibilities as a coach" (p. 344).

The Anderson (1992) court began its analysis of the claims for potential violation of the ADA by noting the statute's legislative history. As the court explained, the purpose of the ADA included remedying 
not only outright intentional exclusion, but also the discriminatory effects of architectural, transportation, and communication barriers, overprotective rules and policies, failure to make modification to existing facilities and practices, and relegation to lesser services, programs, activities, benefits, jobs, or other opportunities (42 U.S.C. § 12101(a)(5)).

Anderson was challenging what he believed to be overprotective rules and policies put in place by Little League Baseball to ensure the safety of the young players as well as Little League's failure to modify its policies so that he could fully participate in their programs in his role as a coach. The court had to consider whether Little League Baseball, before applying its policy to prohibit Anderson from coaching from the field, had conducted an individualized assessment to determine whether Anderson posed a direct threat to the health or safety of others (Anderson, 1992, p. 345). The individualized assessment required by the $\mathrm{ADA}$ is

based on reasonable judgment that relies on current medical knowledge or on the best available objective evidence, to ascertain: (1) the nature, duration, and severity of the risk; (2) the probability that the potential injury will actually occur; and (3) whether reasonable modifications of policies, practices, or procedures will mitigate the risk (28 C.F.R. $\S 36.208(\mathrm{c})$ ).

The Anderson (1992) court determined that there was "no indication" that Little League Baseball had conducted "any type of inquiry," much less the required individualized assessment, necessary to determine whether Anderson did, indeed, pose a "direct threat" to the players (Anderson, p. 345). Noting that Little League Baseball's policy "falls markedly short of the [ADA's] requirements," the court concluded that the policy "amounts to an [sic] absolute ban on coaches in wheelchairs in the coaches box, regardless of the coach's disability or the field or game conditions involved" (p. 345). The court also gave "great weight" to the fact that Anderson had coached Little League Baseball for the previous three seasons on the field without incident (p. 345). The court granted Anderson's request for a temporary injunction which prevented Little League Baseball from interfering with his ability to fully participate in coaching on the field and from intimidating players, parents of players, or coaches because of his participation (p. 346).

The significance of the Anderson (1992) decision is that it illustrates how a court should evaluate whether the service provider has taken the necessary steps to reach an individualized determination that a person with a disability should or should not be allowed to participate given the risks presented. The 
court's emphasis on Little League Baseball's total lack of individualized assessment conducted in implementing their policy served as the impetus for other service providers, including sport and entertainment venues, to reassess, or in some cases, to initially develop the individualized assessment process necessary to properly evaluate the threat posed by the specific individual requesting to participate in their programs or services. Moreover, the Anderson decision supports the notion that "blanket policies disallowing participation based on disability are most likely invalid under the ADA" (Hronek \& Spengler, 2002, p. 292).

The importance of conducting an individualized assessment was again highlighted in the Supreme Court's decision in PGA Tour v. Martin (2001), involving golfer Casey Martin's successful challenge to the PGA's walking requirement for professional golfers competing in PGA Tour events. The central issue in Martin was "whether allowing Martin to use a golf cart, despite the walking requirement that applies to the PGA TOUR ... is a modification that would 'fundamentally alter the nature' of those events'" (Martin, p. 682). The Supreme Court ultimately concluded that Martin's requested waiver of the walking rule would not fundamentally alter the nature of PGA Tour events (p. 690).

Perhaps the most valuable part of the opinion is the Supreme Court's guidance as to the scope and nature of the individualized inquiry that the public accommodation is required to undertake once a request for modification has been made. The Court noted, "an individualized inquiry must be made to determine whether a specific modification for a particular person's disability would be reasonable under the circumstances as well as necessary for that person, and yet at the same time not work a fundamental alteration," emphasizing the fact that the inquiry is focused on the "personal circumstances" of the person requesting modification (Martin, 2001, p. 688). The ADA contemplates three distinct inquiries: "whether the requested modification is 'reasonable,' whether it is 'necessary' for the disabled individual, and whether it would 'fundamentally alter the nature of' the [service]" (Martin, p. 683). The Court added that there is "no necessary priority" among the three questions (p. 683). While the Anderson (1992) and Martin (2001) cases focused on the ADA's right to participate free from discrimination in terms of policies and practices, the scope of this right to participate has now been expanded to include the right to safe evacuation from places of public accommodation. 


\section{Significant Evacuation Cases}

An emerging issue in accommodating patrons with disabilities is how to accommodate their needs during an evacuation of a place of public accommodation. Two prior cases have shed light on this problem and the resulting legal issue. The first significant emergency evacuation case that is relevant to the issue of equality of access to emergency services for sport and entertainment patrons with disabilities is Fiedler v. American Multi-Cinema, Inc. (1994). While Fiedler (1994) is an accommodation request case, the "direct threat" defense raised by the cinema is relevant to understanding the implications for emergency planning.

Fiedler, a quadriplegic wheelchair user, sued the AMC movie theater chain over the lack of accessibility at the Avenue Grand theater located in Union Station in Washington, D.C. (Fiedler, 1994, p. 36). Fiedler discovered that "the only wheelchair seating available ... [at] the Avenue Grand Theater is one of two wheelchair sites situated at the very back of the theater, in the last row of conventional seats farthest from the screen" (Fiedler, p. 36). In his complaint, Fiedler asserted that the arrangement of the wheelchair seating at the theater violated Title III of the ADA because "[b]y relegating him to inferior seating in the back of the theater when he goes to see a movie ....,... $\mathrm{AMC}$ deprives him of full and equal enjoyment of the facilities to which he, as a disabled person, is entitled under the ADA" (p. 36). Fiedler sought injunctive relief which would have required $\mathrm{AMC}$ to re-configure the wheelchair seating at the theater (p. 36).

In response to these allegations, AMC raised the "direct threat" defense, claiming, inter alia, that the ADA "does not require equivalent treatment of the disabled when to do so would present a 'direct threat' to the health or safety of others" (Fiedler, 1994, p. 37). Cited as "AMC's most persuasive argument" to keep its wheelchair seating in the back of the theater, the Fiedler court acknowledged AMC's claim that "the presence of a wheelchair and its occupant in the midst of able-bodied patrons in fear for their own safety could impede a mass exodus of the theater in the case of an emergency" and, as such, constitute a direct threat to health and safety of other theater patrons (Fiedler, p. 39). At the time, the merits of this argument were uncertain, however, as "the courts ha[d] not ruled directly on the issue of whether the direct threat doctrine can be used as a basis to discriminate against an individual with a disability where emergency evacuation from a public accommodation is the concern" (Hollis, 2002, p. 549).

In challenging AMC's application of the "direct threat" defense, Fiedler cited cases, including Anderson v. Little League Baseball (1992) discussed 
above, that have held that "the right to treat a disabled person disparately, and less favorably, on the ground that to do otherwise would endanger others must be preceded by an individualized assessment of the nature and extent of danger in relation to the specific disability of the person to be disfavored" (Fiedler, 1994, p. 39). Fiedler claimed that he posed a de minimis risk to the health and safety of others (Fiedler, 1994). Articulating his own individualized assessment, Fiedler dismissed the threat he posed, given his ability to independently move his own power wheelchair up the aisles as well as the presence of a companion who could assist him in the event of an emergency (Fiedler). He further claimed that because there was a remote likelihood of a theater fire and given the presence of modern fire safety precautions, this rendered the risk to others "virtually non-existent" (Fiedler, p. 39).

The court was not completely convinced by Fielder's self-assessment of the risk he posed, noting that

[i]n event of an emergency evacuation, [Fielder] would be proceeding against substantial crowd traffic heading for nearer exits in the opposite direction. Even those patrons moving in the same direction but behind the wheelchair will be able to proceed only at a pace determined by the ability of the occupant of the wheelchair to propel his or her chair upgrade (p. 40).

The court further noted that "[a] theater fire, moreover, while representing the classic crisis situation, is not the only event that could precipitate the flight of the audience: a bomb threat, a deranged patron with a gun, or a riot could have a similar effect" (p. 40).

The court also distinguished Fiedler's requested relief noting that it "... [was] not concerned with AMC's policies, practices, or procedures, but with its structural amenities" (Fiedler, 1994, p. 40). This distinction is significant because as the court noted,

unlike policies, practices, and procedures - which are more readily adaptable and can be discretely applied in individual cases - structural changes, such as wheelchair seating dispersed throughout a movie theater, once built, would be available not only to Fiedler, but also to other handicapped individuals who may pose a far greater "direct threat" to other patrons than Fiedler (p. 40).

The court, therefore, clarified that the proper

individualized assessment required determin[ing] not only whether Mr. Fiedler's presence... pose[d] a significant risk to his fellow 
theater-goers, but also whether others similarly limited by disability, but less agile or prudent than he, might also do so, and whether AMC can readily achieve an accommodation that might ameliorate the dangers so posed (p. 40).

Given that this determination was a triable issue of fact, the court denied AMC's motion for summary judgment (p. 40).

The court's nuanced approach to the "direct threat" analysis makes this case significant in the disability law jurisprudence because it suggests that the ADA's individualized risk assessment "must be expanded" to encompass "other likely beneficiaries of a structural accommodation when determining if the accommodation eliminates the direct threat to the health or safety of others" (Hollis, 2002, p. 550). For example, the court noted that Fiedler uses a power wheelchair and has ample upper body strength to independently operate his wheelchair up the slope of a ramp in the movie theater and cited Fielder's admission that he does not attend movies with steeply sloped aisles unless he is accompanied by a companion who could assist him (Fiedler, 1994). However, if one, instead, considers a person using a manual wheelchair or a wheelchair user who attends a movie alone, the risks posed by that individual to the health and safety of others during an evacuation or other type of emergency situation may be substantially greater. This hypothetical example confirms the prudence of expanding the direct threat's required individual assessment to take into account any person who could take advantage of the reasonable accommodation.

A more recent case challenging the effectiveness of an evacuation plan for people with disabilities is Shirey v. City of Alexandria School Board (2000), a Title II case with similar facts and legal claims as are typically raised in a Title III evacuation case, such as the Fiedler (1994) case, discussed above. Cady Shirey, a public school student who suffers from a form of dwarfism that necessitates the use of a wheelchair, along with her parents, sued the City of Alexandria School Board for violations of Section 504 of the Rehabilitation Act of 1973 (29 U.S.C . § 794, et. seq., 2006) and Title II of the Americans with Disabilities Act (42 U.S.C. § 12132, 2006). Title II of the ADA applies to "public entities," which has been defined to include any department, agency, special purpose district, or other instrumentality of a state or local government (42 U.S.C. $\S 12131,2006$ ). This provision would include public schools. "Title II of the ADA overlaps substantially with Section 504 of the Rehabilitation Act, because Section 504 applies to any entity receiving federal financial assistance" (Colker, Milani, \& Tucker, 2003, p. 573). Furthermore, the prohibitions against discrimination found in Title II and Section 504 are "nearly identical" and "should provide identical remedies" (Colker, et al., 
2003, p. 573). The alleged violations stemmed from two incidents where Shirey was "left in a school building during an emergency evacuation, as well as alleged defects in the revised emergency plan developed by the School Board" (Shirey, 2000, p. 5). The plaintiffs requested injunctive relief "requiring the school to provide adequate evacuation procedures" as well as compensatory and punitive damages for the harm Shirey suffered (Shirey, p. $5)$.

The first incident alleged in the lawsuit involved the evacuation of the school due to a bomb threat (Shirey, 2000, p. 2). Shirey, an adult, and another child with a disability, were "left in the otherwise evacuated building for approximately seventy minutes" (Shirey, p. 2). After this incident, Shirey's parents filed a complaint with the Office of Civil Rights (OCR) alleging that the School Board "discriminated against [Shirey] on the basis of her disability by failing to evacuate her from the school during the bomb-threat incident" ( $\mathrm{p}$. 3).

The parents and the school board eventually agreed to mediation whereby the School Board was required to adopt a new Emergency Preparedness Plan (Shirey, 2000). This plan was subsequently developed, with input from the Shireys, and included "a procedure whereby, in the event of an emergency, ... . disabled students would be sent to a designated 'safe room'" (Shirey, p. 3-4). Further details of the Emergency Preparedness Plan designated a responsible adult and an alternate for each safe room, which contained a special flag and a cellular phone in order to facilitate communication with school and emergency officials. Furthermore, "[i]f actual evacuation were necessary, emergency personnel would rescue the children directly from the identified safe rooms" (p. 4). The revised emergency plan was put into effect in January, 1997.

In March, 1997, the second incident alleged in the lawsuit occurred, despite the implementation of the revised emergency plan. After an unscheduled fire drill in the school, Shirey went to the safe room designated in the plan (Shirey, 2000, p. 4). "While the other students evacuated the building, [Shirey] was left alone" (Shirey, p. 4). The responsible adult that was assigned to the safe room left the building with the able-bodied children. An alternative responsible adult was en route to the safe room which left Shirey unattended for approximately two minutes.

In analyzing the claims for violation of the Rehabilitation Act (29 U.S.C . 794, et. seq. (1973)) and Americans with Disabilities Act (42 U.S.C. 12101 et seq. (1990)), the court first considered the impact of the previous OCR agreement reached between the Shirey's and the School Board covering the first incident discussed above. The court determined that because "[t]he right to file a disability discrimination claim under the Rehabilitation Act and the 
ADA is a statutory right created by Congress," the OCR Agreement could not bar the Shirey's federal claim unless the OCR agreement "contains a knowing and intelligent waiver of the Plaintiffs' right to bring such a claim" (Shirey, 2000 , p. 9). Upon finding that language in the agreement was not sufficient to constitute such a waiver of Shirey's federal claims, the court considered both the bomb threat and fire alarm incidents in their analysis (Shirey, p. 9-10).

Because the language and purpose of both the Rehabilitation Act and ADA is substantially the same, "the same analysis applies to claims brought under both statutes" (Doe v. University of Md. Med. Sys. Corp., 1995). The Rehabilitation Act provides that "No otherwise qualified individual with a disability ... shall, solely by reason of her or his disability, be excluded from the participation in, be denied the benefits of, or be subjected to discrimination under any program or activity receiving Federal financial assistance ..." (29 U.S.C. $\S 794(a))$. Meanwhile, Title II of the ADA applies to public entities, which includes public schools. The relevant language states "No qualified individual with a disability shall, by reason of such disability, be excluded from participation in or be denied the benefits of the services, programs, or activities of a public entity or be subjected to discrimination by any such entity" (42 U.S.C. $\S 12132$ ). In order to establish a prima facie case of discrimination under either the Rehabilitation Act or the ADA, the plaintiff must prove: "(1) that she has a disability; (2) that she is otherwise qualified for the benefit or program in question, and (3) that she was excluded from the benefit or program due to discrimination solely on the basis of the disability" (Doe, 1995, p. 1265).

In conducting its analysis, the court had to consider "whether the School Board's actions ha[d] denied [Shirey] and other disabled students access to the program in question - namely safe evacuation from school buildings during an emergency" (Shirey, 2000, p. 13-14). In analyzing the second incident involving the fire alarm, the court found sufficient evidence to conclude that Shirey was not excluded from safe evacuation procedures due to the implementation of the revised Emergency Preparedness Plan (Shirey, p. 14). Therefore, the School Board incurred no liability under either Act (p. 14). In a footnote, the court explained that the "imperfect execution of an otherwise reasonable evacuation plan" does not constitute disability discrimination and that "[m]inor errors in carrying out the evacuation plan are not a sufficient basis for a discrimination claim" (p. 14).

In analyzing the first incident involving the bomb threat, however, the court found that Shirey "was excluded from safe evacuation procedures" as a result of the School Board's failure to have "a reasonable plan in place to evacuate children with disabilities from school buildings during an 
emergency" (Shirey, 2000, p. 15). Upon finding that the School Board was liable for violations of the Rehabilitation Act and the ADA, the Court determined that the corrective injunctive relief was to require the School Board to develop and implement a reasonable emergency evacuation plan (Shirey, 2000). However, because the School Board had already done as such, the court concluded that no other relief was necessary (Shirey). The Fiedler (1994) and Shirey (2000) cases stress the importance of inclusion of the needs of people with disabilities in the plan and suggest that the failure to make provisions for such needs in the plan can expose the entity to potential litigation.

\section{SECTION TWO: SAVAGE V. CITY PLACE LIMITED PARTNERSHIP: AN IMPORTANT CASE IN THE EVOLUTION OF EQUALITY OF ACCESS TO EMERGENCY EVACUATION}

The most recent case to address the requirement to provide access to emergency services is Savage, et al. v. City Place Limited Partnership, et al. (2004). In the Fall of 2002, Katherine Savage, a wheelchair user, was shopping at a Marshalls department store, when the fire alarm was activated and customers were told to evacuate the store, located on the second floor of a shopping mall. "Savage did not receive any assistance or guidance from store or mall personnel" (Washington Lawyers' Committee for Civil Rights \& Urban Affairs, n.d., p. 1). "[She] was required to exit into an area of the mall that is below ground level" (Washington Lawyers' Committee for Civil Rights \& Urban Affairs, n.d., p. 1). However, the mall's elevators were inoperable due to the emergency, leaving the only accessible exit route by stairs (Savage, 2004). Given her physical limitations, Savage became trapped and was unable to evacuate until after the emergency was over.

Based on the incident, Savage and a disability advocacy group filed suit in Maryland state court against Marshalls as well as the operator of the mall for violations of Title III of the ADA, as well as filed tort claims for negligence and false imprisonment. In cross motions for summary judgment presented to a Maryland Circuit Court judge, the plaintiffs alleged that Marshalls violated the ADA by failing to "design evacuation procedures that comply with Title III of the ADA" (Savage, 2004, p. 6). Marshalls countered that its evacuation plans could not violate the ADA since Title III does not contain any specific rules for a public accommodation's emergency evacuation plans (Savage, p. 9). The plaintiffs cited PGA Tour, Inc. v. Martin (2001) to argue that Title III applied to Marshalls' policies. The court agreed, stating "Martin seems to make it clear that Title III applies to the policies of a public accommodation" 
(Savage, 2004, p. 9). Moreover, the court found that "a store's nationwide evacuation procedures would certainly constitute a public accommodation's policies" (Savage, p. 9-10).

In response, Marshalls argued that the plaintiff's suggested modifications would not be reasonable because it would "fundamentally alter the nature of Marshalls services" (Savage, 2004, p. 10). Marshalls also alleged that the suggested modifications were not reasonable because the changes suggested imposed "too many administrative burdens," stating that it would require "coordinating [the evacuation procedures at] all of their 673 stores and negotiating new lease terms with 673 landlords" (Savage, p. 10). On the issue of administrative burden, the court noted that the burden would be eased by the fact that "the number of stores that do not have proper exits for the disabled would be considerably less than 673" (p. 10). Finding that both the plaintiff and defendants had raised issues and presented evidence that could satisfy their respective burdens, both plaintiff's and defendant's motions for summary judgment were denied (p. 10-11).

The case eventually settled in March, 2005. In addition to a confidential financial settlement between the parties, Marshalls agreed to do the following:

...[C]ertify that each of its stores... provides an accessible emergency exit for people with disabilities. To be accessible, the emergency route must either (1) provide a continuous means of exit during emergencies, or (2) contain or connect to an area of rescue assistance where a person with disabilities can wait for help. . . . . .

... [C]ertify that all of its store managers are trained to assist customers in locating and using a store's accessible evacuation routes; that emergency announcements include instructions for people with disabilities; and that signs in each store direct people with disabilities to accessible emergency exits.

... [D]evelop written corporate-wide policies and procedures for the evacuation of people with disabilities... [which] will be reviewed once per year.

... [T]rain all management employees on its new evacuation policies, and management shall, in turn, train all current and future store employees. ("Overview of Marshalls Settlement Agreement," n.d.).

Commenting on the settlement in what disability advocates have called a "landmark case," it was recognized that "... Marshalls becomes the first retailer in the country to agree to address the critical emergency evacuation needs of persons with disabilities" (NOD, 2005a, p. 1). Echoing the same 
sentiment, the acting director of the National Organization on Disability's Emergency Preparedness Initiative, Hilary Styron, stated:

The settlement is a significant step in ensuring the safety of all, not just disabled consumers. It serves as a model for other retailers. Any business that does not take this preparedness issue into account could be setting itself up for legal liability, embarrassment, and tragedy (NOD, 2005b, pg. 1).

While the Savage ruling has been heralded as a "precedent-setting lawsuit" by disability advocates (NOD, 2005a, pg. 1), its legal significance or precedential value should be viewed cautiously. The ruling is from an unreported lower state court. Therefore, the precedential impact of the ruling may be minimal. However, the ruling in the plaintiffs' favor demonstrates that the arguments made were based on sound reasoning which could later be followed by a federal court in a future case.

The Savage case is an important development in the evolution of the legal issues related to emergency evacuation. Recall that prior to the ruling in Savage, no court had ruled that companies subject to Title III of the ADA were required to incorporate the needs of people with disabilities in their evacuation plans (NOD, 2005a). With the Savage ruling, the legal landscape has arguably shifted closer to the recognition that accessible evacuation procedures are required under the ADA (Savage, 2004; NOD, 2005a).

Soon after the Marshalls settlement was announced, U.S. Department of Justice spokesman Eric Holland commented on the state of the law with regard to emergency evacuation for people with disabilities. He stated that the ADA "does not specifically address evacuation plans in public buildings but that provisions of the act indicate that stores with public access 'would have to take people with disabilities into account when developing evacuation plans"' (NOD, 2005a, p. 1). Reconciling the Savage ruling and the statement from the Justice Department suggests that places of public accommodation are already (or may soon be) obligated to ensure that accessible evacuation procedures are in place for people with disabilities. Moreover, the eventual settlement between Marshalls and the plaintiff in this case is at least a tacit acknowledgement that considering the needs of customers with disabilities with regard to emergency evacuation is now an integral part of compliance with the ADA.

The Savage (2004) ruling may have a much greater impact on policy development and practice. The increased awareness of the needs of people with disabilities during emergencies which has been spurred by the attention in this case should benefit the disability community and assist those entities that 
serve patrons with disabilities in identifying deficiencies in their current emergency plans. The Savage settlement "establish[es] access to emergency services for thousands of people with disabilities across the country" not only in the affected Marshalls stores but beyond as other service providers heed the ruling and make changes in their policies and procedures (Washington Lawyers' Committee for Civil Rights \& Urban Affairs, n.d.). From a policy perspective, the settlement should also have a lasting impact on improving safety for people with disabilities in places of public accommodation. Katherine Savage, the plaintiff, called the settlement "an agreement which recognizes that people with disabilities are not second-class citizens, and that [their] safety is just as important as others in the event of an emergency" (Washington Lawyers' Committee for Civil Rights \& Urban Affairs, n.d., p. 2). In response to the settlement, the director of the Disability Rights Project at the Washington Lawyer's Committee for Civil Rights and Urban Affairs commented:

The settlement... is a significant step in ensuring the safety of consumers with disabilities, and should serve as a model for other[s].... The ADA has always been understood to help get people with disabilities into places of public accommodation. Now, for the first time, it also works to ensure that public places try to get those same people out in the event of a fire, terrorist attack, or other emergency (Washington Lawyers' Committee for Civil Rights \& Urban Affairs, n.d., p. 1, emphasis in original).

One of the plaintiff's lawyers suggested that the effects of the settlement will have a much wider reach beyond the instant case "because governments can seek guidance from the way the law is interpreted for public accommodations under the ADA" (Washington Lawyers' Committee for Civil Rights \& Urban Affairs, n.d., p. 2). Therefore, the Savage settlement "should have significance not just to commercial landowners, but also to state, local, and federal agencies who are designing their evacuation plans" (Washington Lawyers' Committee for Civil Rights \& Urban Affairs, n.d., p. 2). As a result of the Savage (2004) ruling, those entities subject to the ADA "should now seek to accommodate people with disabilities in the development and modification of emergency evacuation procedures" (Washington Lawyers' Committee for Civil Rights \& Urban Affairs, n.d., p. 1). The Savage case has the potential to spur "system-wide change" which will "lead to not only a better awareness of emergency issues for people with disabilities but improved safety for all people" (NOD., 2005a, p. 1). 


\section{SECTION THREE: RECOMMENDATIONS FOR RISK MANAGEMENT STRATEGY}

The Savage case and the resulting settlement create the impetus for sport and entertainment venue managers to ensure the inclusion of the needs of patrons with disabilities when developing emergency procedures. Based upon the general emergency planning literature, several recommendations, outlined below, are proposed to effectively incorporate the needs of patrons with disabilities into the existing emergency management plan and as part of the venue's overall risk management plan.

First, venue managers should develop a comprehensive emergency management plan that accounts for individuals with disabilities. While it would seem intuitively obvious, plan developers should include people with disabilities as consultants when developing an emergency management plan. These individuals may be found by contacting local disability rights groups for input. Individuals with disabilities are often left out of planning activities such as analyzing and documenting the possibility of an emergency or disaster and the potential consequences or impacts on life, property, and the environment (National Council on Disability, 2005). These activities include assessing the hazards, risks, mitigation, preparedness, response, and recovery needs. Members of the emergency management community must learn to discuss and think about a broad range of issues related to people with disabilities, including not only the range of disabilities but also how to integrate people with disabilities into the existing emergency services (National Emergency Training Center Emergency Management Institute, 1993).

An important factor to consider during the development of an emergency management plan is the layout of the building. Physical access, which allows individuals to get to, into, and around facilities, should be maximized. This process may involve the removal of architectural barriers such as curbs and steps, narrow exterior and interior doorways and aisles, narrow rest room doorways and stalls, and inaccessible parking spaces, food service, drinking fountains, and telephones (National Council on Disability, 2005). It is important to not only consider the accessibility of the building's exits, but also the paths of travel to the exit, which will vary based upon the type of disability. For example, someone who is deaf or hard of hearing can follow the same path of travel as someone who is not disabled, while someone using a wheelchair may not.

Another factor one should take into account during plan development is the identification of people with disabilities who are present in the building. 
While it may be impossible to always account for all disabled individuals in the building due to random visits from customers, guests, and visitors, knowledge of regular visitors to the building, such as employees, is necessary in order to develop an effective evacuation plan. The use of a daily roll call and sign-in sheet can help ensure that everyone is evacuated in the event of an emergency. To assess the needs of employees in a respectful manner, it is recommended to draft a memo to all employees inquiring about their needs in an evacuation. Such information will prove to be invaluable when developing a successful emergency management plan. Further, employees who may be temporarily disabled (i.e., a broken leg), should be aware of a designated person to contact within the organization to inform them of their condition.

Second, venue managers should implement and regularly practice their emergency management plan through disaster simulations. A comprehensive training program is the cornerstone of every effective emergency management plan. While many evacuation plans adopt the "buddy system" to account for individuals with disabilities, the entire staff should be trained so that anyone can assist a person with a disability in unforeseen circumstances. Further, staff members should be aware of and able to operate any special equipment (i.e., portable evacuation chairs) that has been purchased to assist individuals with disabilities during the evacuation process.

Venue managers should also ensure appropriate signage is posted throughout the building that illustrates a means of egress in all primary function and public areas. If the path taken by someone with a disability is different than the path used by the general public, the signage should reflect these multiple paths of travel. Fried and Ammon (2001) noted that "appropriate signage is critical because it can help create a safer environment, serve as a public relations tool, [and] assist with customers ..." (p. 181). In addition, venue managers should consult with local fire, police, emergency medical technicians, and the Office of Emergency Management to gain their valuable input about local requirements, areas of rescue, exits, and possible locations of people with disabilities. These agencies may be willing to evaluate the venue's current emergency management plan and make suggestions for enhancement. Obviously, the evacuation plan should be updated regularly to account for changes in the building and the people in it.

Finally, venue managers should publicize and advertise their emergency management plan. Since major sporting events regularly attract tens of thousands of spectators, it is important to communicate the evacuation plan prior to an emergency. The communication of such a plan could potentially reduce the higher anxiety levels experienced by individuals with disabilities when compared to the general population about future disasters and 
emergencies (N.O.D., 2004). Two examples of such communication efforts are provided by Yankee Stadium and Lincoln Financial Field. According to the New York Yankees' website (n.d.),

Yankee Stadium personnel have been trained in emergency evacuation procedures to ensure the safe evacuation of all patrons, including those Guests with disabilities. Should an emergency evacuation situation occur, emergency information will be displayed on the Stadium Scoreboard and announced on the public address system. Additional personnel will proceed to the accessible seating areas to provide assistance to Guests with disabilities.

Similarly, the Lincoln Financial Field website (n.d.), in their Guide for Guests with Disabilities, states "The staff at Lincoln Financial Field has been trained in proper procedures for emergency preparedness. These designated employees have the primary duty of assisting Guests with disabilities to safe locations." Although it seems counterintuitive, emergency preparedness information often is not available in accessible formats (e.g., Braille, large print, disks, audio cassettes, and accessible media, including Web sites or captioned and audio-described films and videos). Therefore, venue managers should ensure their emergency management plan is capable of being effectively communicated to all parties of interest.

\section{CONCLUSION}

Equality of access to emergency planning at sport and entertainment venues is a critical concern for people with disabilities who patronize such facilities. While the ADA guarantees people with disabilities will be free from discrimination in places of public accommodation, such persons in emergency situations have historically found emergency plans to be either completely unable to meet their needs or plans which were inferior to those afforded ablebodied patrons. Now, given recent judicial interpretation as well as an emerging awareness of the needs of people with disabilities during an emergency, the goal of true equality of access to emergency evacuation has begun to be realized.

\section{ABOUT THE AUTHORS}

JOHN GRADY is an Assistant Professor in the Department of Sport and Entertainment Management at the University of South Carolina, where he teaches courses in sport law, business law, and risk management. He earned his Ph.D. from the Florida State University and his J.D. from the Florida State 
University College of Law. His research interests focus on the implementation of the Americans with Disabilities Act by the sport and entertainment venue industries as well as intellectual property issues in sport.

DAMON P. S. ANDREW is an Assistant Professor of Sport Management in the Department of Exercise, Sport, and Leisure Studies at The University of Tennessee. He received his Ph.D. in Sport Administration from Florida State University. His research interests include leadership in sport, the attraction of sport to participants, spectators, sponsors, employees, and stakeholders, and the effective integration of individuals with disabilities into the sporting environment. Dr. Andrew's work has been published in outlets such as the International Journal of Sport Management and Marketing, Sport Marketing Quarterly, International Journal of Sport Management, Journal of Legal Aspects of Sport, Journal of Contemporary Athletics, International Journal of Coaching Science, Journal of Physical Education Recreation \& Dance, The Physical Educator, Journal of Science and Medicine in Sport, and the Journal of Sport Rehabilitation.

\section{REFERENCES}

Access Board (n.d.). Resources on emergency evacuation and disaster preparedness. Retrieved October 8, 2006, from http://www.accessboard.gov/evac.htm.

ADA Title III Technical Assistance Manual (1993). Retrieved October 8, 2006, from http://www.ada.gov/taman3.html.

Americans with Disabilities Act, 42 U.S.C. §12101, et. seq. (2006).

Anderson v. Little League Baseball, Inc., 794 F.Supp. 342 (D.Ariz. 1992).

Byzek, J., \& Gilmer, T. (2001). September 11, 2001: A day to remember. New Mobility 12, 20-21.

California Department of Rehabilitation. (1997). Disaster preparedness for persons with disabilities improving California's response. Retrieved September 1, 2006, from http://www.oes.ca.gov/Operational/OESHome.nsf/ PrintView/66952778A6D2FA7C88256CEF006A8967?OpenDocument.

California State Independent Living Council. (2004). Issue brief resulting from Southern California fire forums-The impact of 2003 wildfires on people with disabilities. Retrieved September 1, 2006, from http://www.calsilc.org/ impactCAWildfires.pdf 
Center for Independence of the Disabled. (2004). Lessons learned from the World Trade Center Disaster: Emergency preparedness for people with disabilities in New York. Retrieved September 1, 2006, from http://www.jik.com/Disaster-lessons-CIDNYWTCpaper.doc

Colker, R, Milani, A.M., \& Tucker, B.P. (2003). The Law of Disability Discrimination (4th ed.). Cincinatti, OH: Anderson Publishing Co..

Doe v. University of Md. Med. Sys. Corp., 50 F.3d 1261 (4th Cir. 1995).

Fiedler v. American Multi-Cinema Inc., 871 F. Supp. 35 (D.D.C. 1994).

Fried, G., \& Ammon, R. (2001). What is appropriate signage for the sport industries? Journal of Legal Aspects of Sport, 11, 181-208.

Hollis, W.C. (2002). Rights of people with disabilities to emergency evacuation under the Americans with Disabilities Act of 1990. Journal of Health Care Law \& Policy, 5, 524-563.

Hronek, B.B., \& Spengler, J.O. (2002) Legal liability in recreation and sports (2nd ed.). Champaign, IL: Sagamore Publishing.

Kailes, J. (2000). Creating a disaster-resistant infrastructure for people at risk including people with disabilities. Trauma Treatment Professionals' Training. A. Tufan, Duyan, Hacettepe University, School of Social Work, Series No: 005, Universitesi, Sosyal Hizmetler Yuksekokulu, Faith Caddesi No: 195 Ciftasfalt, 06290 Kecioren - ANKARA. 005.

Lincoln Financial Field (n.d.). Guide for guests with disabilities. Retrieved September 6, 2006, from http://www.lincolnfinancialfield.com/ guest/disabilities.jsp.

McGuire, K.G. (2005, April). Developing a building evacuation plan for people with disabilities. The BOMA Magazine. Retrieved February 27, 2006 from $\mathrm{http} / /$ www.fmlink.com/ProfResources/Magazines/article.cgi?BOMA:boma0 405b.htm.

National Council on Disability. (2005, April 15). Saving lives: Including people with disabilities in emergency planning. Retrieved January 26, 2007, from http://www.ncd.gov/newsroom/publications/2005/ saving_lives.htm.

National Emergency Training Center Emergency Management Institute. (1993). Workshop in Emergency Management: Disaster-Related Needs of the Elderly and Persons with Disabilities: Curriculum Advisory Committee, July 19-21, 1993. 
National Organization on Disability ("NOD"). (2001). National Organization on Disability 2001 annual report. Retrieved September 1, 2006, from http://www.nod.org/resources/PDFs/2001annrpt.pdf.

National Organization on Disability ("NOD"). (2004). New poll highlights need for more emergency planning for and by people with disabilities, http://www.scienceblog.com/community/older/archives/K/4/pub4308.html

National Organization on Disability ("NOD"). (2005a, May 4). Accessible evacuation procedures required: A landmark case. Retrieved January 30, 2007 from http://www.nod.org/index.cfm?fuseaction=page.viewPage\&page $\mathrm{ID}=1430 \&$ nodeID $=1 \&$ FeatureID $=1509 \&$ redirected $=1 \& \mathrm{CFID}=5178983 \& \mathrm{CF}$ TOKEN=33661331.

National Organization on Disability ("NOD"). (2005b, May 5). N.O.D.'s response to the Marshalls court ruling. Retrieved October 6, 2006, from http://nod.org/index.cfm?fuseaction=page.viewPage\&pageID=1430\&nodeI $\mathrm{D}=1 \&$ FeatureID $=1511 \&$ redirected $=1 \& \mathrm{CFID}=5178983 \& \mathrm{CFTOKEN}=33661$ 331.

Nondiscrimination On The Basis Of Disability By Public Accommodations And In Commercial Facilities, 28 C.F.R. §36.101, et. al. (2000).

New York Yankess (n.d.). Guests with disabilities. Retrieved September 6, 2006 from http://newyork.yankees.mlb.com/NASApp/mlb/nyy/ticketing/ accessibility.jsp.

Overview of Marshalls settlement agreement (n.d.). Retrieved October 6, 2006, from http://www.nod.org/Resources/PDFs/savage2.pdf\#search $=\% 22$ nod $\%$ 20overview $\% 20$ of $\% 20$ settlement $\% 20$ marshalls $\% 22$.

PGA Tour Inc. v. Martin, 532 U.S. 661 (2001).

Pollander, G. S., \& Rund, D. A. (1989). Analysis of medical needs in disasters caused by earthquake: The need for a uniform injury reporting scheme. Disasters, 13(4), 365-369.

Rehabilitation Act, 29 U.S.C . §794, et. seq. (2006).

Reis, J. P., Breslin, M. L., Iezzoni, L., \& Kirschner, K. (2004). It takes more than ramps to solve the crisis of healthcare for people with disabilities. Chicago, IL: Rehabilitation Institute of Chicago.

Savage, et al. v. City Place Limited Partnership, et al., No. 240306-V (Cir. Ct. Montgomery County, Md.) (2004). Retrieved October 10, 2006, from http://www.washlaw.org/pdf/Opinion_12_28_04.pdf. 
Shirey ex rel. Kyger v. City of Alexandria School Bd., 229 F.3d 1143 (4th Cir. 2000).

U.S. Architectural and Transportation Access Board ("Access Board") (n.d.). Americans with Disabilities Act (ADA) guidelines for buildings and facilities (As amended through September 2002). Retrieved October 8, 2006, from http://www.access-board.gov/adaag/ADAAG.pdf.

U.S. Department of Justice. (2004). Project Civic Access, http://www.usdoj.gov/ crt/ada/civicac.htm.

Washington Lawyers' Committee for Civil Rights \& Urban Affairs (n.d.). Landmark settlement requires accessible evacuation procedures at Marshalls stores nationwide. Retrieved October 6, 2006, from http://www.nod.org/ Resources/PDFs/savage1.pdf.

White, G., Fox, M., Rowland, J., Rooney, C., \&, Aldana, S. (2004). Nobody left behind: Investigating disaster preparedness and response for people with disabilities. Power Point presentation at the National Advisory Board Meeting, Lawrence, Kansas, May 24. 